\title{
NILAI PERBANDINGAN UJI FISIS DAN MEKANIK PAPAN KOMPOSIT DENGAN MENGGUNAKAN BAHAN DASAR ORGANIK
}

\author{
Maulida Ilyas ${ }^{1}$, Hernawati ${ }^{1}$ \\ ${ }^{1}$ Jurusan Fisika UIN Alauddin Makassar \\ E-mail: maulidailyas004@gmail.com
}

\begin{abstract}
Abstrak: Telah dilakukan penelitian perbandingan uji fisis dan mekanik papan komposit dengan menggunakan bahan dasar organik untuk mengetahui metode yang digunakan dalam pembuatan papan komposit dari bahan organic dan mengetahui bahan organik yang paling baik untuk dijanikan sebagai bahan papan komposit. Sampel yang digunakan sebagai bahan dasar organik pembuatan papan komposit yaitu kulit singkong, batang pandan, kayu akasia, bambu kuning, serbuk gergaji kayu, sekam padi, limbah kayu industri, bambu hutan, sabut kelapa, dan daun jambu dengan menggunakan berbagai jenis bahan perekat yang bervariasi. Papan komposit dengan kualiatas terbaik ada papan yang terbuat dari kayu Akasia dengan campuran Phenol Formaldehyde denganhasil pengujian nilai uji daya serap air, uji elastisitas, kerapatan, modulus patah, keteguhan rekat, dan kuat pegang sekrup pada papan komposit dengan bahan dasar kulit singkong secara berurut adalah $34,35 \%, 57116,34 \mathrm{Kg} / \mathrm{cm} 2,0,7453 \mathrm{gr} / \mathrm{cm} 3$, $473,4539 \mathrm{~kg} / \mathrm{cm} 2,9,0261 \mathrm{~kg} / \mathrm{cm} 2$, dan $118,1140 \mathrm{Kg}$.
\end{abstract}

Kata Kunci: Bahan organik, Papan komposit, Pengujian mekanik, Pengujian fisis

\section{PENDAHULUAN}

$\mathrm{P}$ enggunaan kayu dewasa ini semakin meningkat dengan semakin meningkatnya pengembangan pembangunan dewasa ini. Kayu menjadi pilihan utama bagi masyarakat karena mempunyai beberapa keunggulan salah satunya adalah kayu mudah dibentuk, mudah dalam pengerjaannya dan memiliki dekoratif serat yang indah.

Kelemahan dari kayu adalah sangat mudah diserang oleh serangga perusak kayu karena kayu mengandung lignin sellulosa, sehingga pemakaian kayu tidak bisa digunakan dalam jangka lama. Untuk mengatasi masalah tersebut maka perlu suatu alternative pengganti kayu yang dapat menggantikan penggunaan kayu tersebut (Febriana Tri Wulandari, 2013).

Papan partikel merupakan salah satu alternatif dalam pemenuhan kebutuhan kayu. Papan partikel dibuat dari potongan-potongan kayu kecil (limbah kayu) maupun dari bahan berlignoselulosa lainnya. Kebutuhan papan partikel terus meningkat. Tiap bulannya satu pabrik mebel (furniture) membutuhkan paling sedikit $3.000 \mathrm{~m}^{3}$ papan partikel, yang sebagian besar diimpor dari China dan Italia karena minimnya pasokan lokal (Muhdi, 2013). 
Teknologi papan partikel atau papan komposit telah banyak dikembangkan oleh peneliti baik yang menggunakan bahan nonorganik maupu yang menggunakan bahan organik. Pembuatan papan komposit dengan bahan dasar batang singkong, pandan, beberapa jenis kayu seperti kayu akasia, bambu, padi, jerami, dan limbah industri kayu adalah beberapa penelitian yang sebelumnya telah dilakukan dengan menambahkan beberapa campuran bahan kimia.

Untuk hasil yang diperoleh dari penelitian tersebut memiliki kekurangan dan kelebihan masing-masing yang kemudian menjadi latar belakan dilaksanakannya penelitian ini untuk mengetahui perbandingan hasil penelitian pembuatan papan komposit yang menggunakan bahan dasar organik dengan menggunakan pengujian mekanik dan pengujian fisis.

\section{TUJUAN PENELITIAN}

Tujuan dari penelitian ini adalah :

1. Untuk mengetahui metode yang digunakan dalam pembuatan papan komposit dengan menggunakan bahan dasar organik.

2. Untuk mengetahui bahan organik yang memiliki kualitas terbaik untuk dijadikan sebagai bahan dasar papan komposit.

\section{TINJAUAN PUSTAKA}

\section{A. Papan Komposit}

Berbagai upaya dilakukan untuk mengatasi kekurangan bahan baku kayu, diantaranya dengan mensubstitusi penggunaan kayu yang selama ini dipergunakan. Salah satu bahan yang dapat digunakan sebagai substitusi penggunaan kayu adalah papan komposit. Papan semen merupakan salah satu produk papan komposit kayu yang dibuat dari campuran partikel kayu atau bahan berlignoselulosa lainnya dengan semen sebagai perekat (Ratu Fortuna, 2009).

Papan komposit adalah lembaran hasil pengempaan panas campuran serbuk gergaji atau partikel kayu atau bahan berlignoselulosa dengan limbah plastik sebagai bahan pengisi sekaligus sebagai bahan perekat tambahan dan perekat pencampuran perekat organik dan bahan lainnya (Sushardi, 2015).

Bahan organik yang dapat digunakan untuk membuat papan komposit adalah batang singkong (Ronnika Rita, 2015), batang pandan (Daeng Maulana, 2015), kayu akaisa (Muhdi, 2013), bambo (Dina Setyawati, 2008), limbah industri kayu (Sushardi, 2015), padi (Ratu Fortuna, 2009), dan jerami (Farid Maulana, 2011).

Menurut Dinas kehutanan (2009), Produksi singkong di Kalimantan Barat berasal dari Kabupaten Landak, Sintang, dan Pontianak. Saat ini produksi singkong Kalimatan Barat mencapai 221,630 ton pada tahun 2008. Batang singkong merupakan bahan yang berlignoselulosa yang dapat dimanfaatkan sebagai bahan baku papan komposit plastic (Ronnika Rita, 2015). lignoselulosa yang memiliki potensi untuk dijadikan bahan baku pembuatan panel kayu salah satunya adalah Pandan Mengkuang (Pandanusatrocarpus Griff) (Daeng Maulana, 2015).

Papan partikel dibuat dari potongan-potongan kayu kecil (limbah kayu) maupun dari bahan berlignoselulosa lainnya seperti kayu akasia (Muhdi, 2013). Selain itu 
limbah kayu dapat dimanfaatkan menjadi bahan dasar untuk pembuatan papan partikel (particle board). Dengan diprosesnya limbah kayu menjadi partikel diharapkan limbah kayu yang selama ini dihasilkan oleh industri penggergajian dapat dimanfaatkan (Dini Cahyandani, 2007).

Padi merupakan salah satu limbah pertanian yang cukup besar jumlahnya dan belum juga sepenuhnya dimanfaatkan. Mengingat ketersediaan dan pengunaannya yang belum dioptimalkan maka penggunaan jerami sebagai bahan baku pembuatan komposit sangat menjanjikan (Farid Maulana, 2011).

\section{B. Daya Serap Air}

Daya Serap Air adalah kemampuan dari papan partikel dalam menyerap airselama dilakukan perendaman 24 jam. Air tersebut mengisi ruangruang kosong dalam papan (Muhdi, 2013). Pengujian daya serap air dilakukan bersamaan dengan pengujian pengembangan linear dan tebal. Contoh uji ditimbang kemudian direndam dalam air dingin selama 2 jam dan 24 jam, kemudian contoh uji ditimbang kembali. Nilai daya serap dapat dihitung dengan menggunakan rumus :

$$
\text { Daya serap air }=\frac{\mathrm{B}_{2}-\mathrm{B}_{2}}{\mathrm{~B}_{1}} \times 100 \% \ldots \ldots \ldots \ldots \ldots
$$

Keterangan:

B1 : Berat contoh uji sebelum perendaman (gr)

B2 : Berat contoh uji setelah perendaman (gr)

(Ratu Fortuna, 2009).

\section{Kerapatan Papan Komposit}

Kerapatan merupakan salah satu sifat fisis dari papan komposit yang didefinisikan sebagai massa per satuan volume material, bertambah secara teratur dengan meningkatnya nomor atomik pada setiap subkelompok. Kerapatan dapat ditentukan dengan metode "pencelupan" biasa, tetapi untuk keperluan pembelajaran diperkenalkan penggunaan metode sinar-X. kerapatan bergantung pada massa atom, ukuran serta cara penumpukannya. berikut:

Besarnya kerapatan papan komposit dapat dihitung menggunakan persamaan

$$
\rho=\frac{\mathrm{m}}{\mathrm{V}}
$$

$$
\begin{gathered}
\text { Dimana }: \rho=\operatorname{kerapatan}\left(\mathrm{kg} / \mathrm{m}^{3}\right) \\
\mathrm{m}=\operatorname{Massa}(\mathrm{kg}) \\
\mathrm{V}=\operatorname{Volume}\left(\mathrm{m}^{3}\right)
\end{gathered}
$$

(Desi, 2016).

\section{Modulus Patah}

Modulus of Rupture (MOR) adalah merupakan keteguhan patah dari suatu balok yang dinyatakan dalam besarnya tegangan per satuan luas, yang mana dapat dihitung dengan menentukan besarnya tegangan pada permukaan bagian atas dan bagian bawah dari balok pada beban maksimum (Ratu Fortuna, 2009). 
Secara umum, modulus patah dapat dihitung dengan menggunakan rumus:

$$
\sigma_{b}=\frac{M \cdot Y_{\max }}{I}
$$

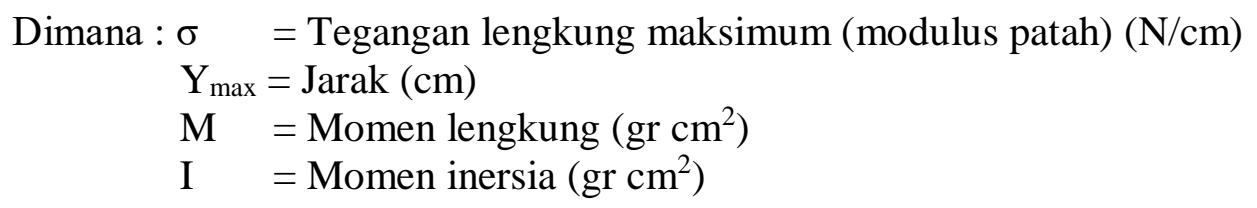

Modulus patah papan partikel dapat dihitung dengan menggunakan rumus:

$M O R=\frac{3 P L}{2 b d^{2}}$

Dimana $:$ MOR $=$ Modulus of Rupture $($ modulus patah $)\left(\mathrm{kgf} / \mathrm{cm}^{2}\right)$

$$
\begin{aligned}
& \mathrm{P}=\text { Berat maksimum }(\mathrm{kgf}) \\
& \mathrm{L} \quad=\text { Panjang bentang }(\mathrm{cm}) \\
& \mathrm{b} \quad=\text { Lebar contoh uji }(\mathrm{cm}) \\
& \mathrm{d} \quad=\text { Tebal contoh uji }(\mathrm{cm})
\end{aligned}
$$

(Desi, 2016).

\section{E. Keteguhan Rekat Internal (Internal Bond)}

Keteguhan rekat internal merupakan ukuran tunggal terbaik tentang kualitas pembuatan suatu papan karena menunjukkan kekuatan ikatan antara partikel-partikel (Ratu Fortuna, 2009).

\section{F. Kuat pegang sekrup}

Kuat pegang sekrup dilakukan untuk menunjukkan kemampuan papan semen untuk menahan sekrup yang ditanam pada papan (Ratu Fortuna, 2009).

\section{G. Modulus Elastis}

Keteguhan Lentur (Modulus of Elasticity/ MOE) merupakan ukuran ketahanan kayu dalam mempertahankan perubahan bentuk akibat adanya beban dan berhubungan langsung dengan kayu. Semakin tinggi nilai MOE, maka semakin elastis (Muhdi, 2013).

Spesifikasi sifat-sifat papan komposit menurut standar SNI 03-2105-2006 dapat dilihat pada tabel berikut:

Tabel 1. Spesifikasi Sifat-sifat Fisis Material Menurut Standar SNI 03-2105-2006

\begin{tabular}{cllc}
\hline No & \multicolumn{1}{c}{ Sifat Fisis } & Nilai Standar & Ukuran Sampel $(\mathbf{c m})$ \\
\hline 1 & Kerapatan $\left(\mathrm{gr} / \mathrm{cm}^{3}\right)$ & $0,4-0,9$ & $10 \times 10$ \\
\hline 2 & Kadar Air $(\%)$ & 14 Maks & $10 \times 10$ \\
\hline 3 & Pengembangan Tebal $(\%)$ & $12-25$ maks & $5 \times 5$ \\
\hline 4 & Modulus Elastisitas $(\mathrm{MOE})\left(\mathrm{Kg} / \mathrm{cm}^{2}\right)$ & $2,55 \mathrm{~min}$ & $5 \times 20$ \\
\hline 5 & Modulus Patah $(\mathrm{MOE})\left(\mathrm{Kg} / \mathrm{cm}^{2}\right)$ & $133 \mathrm{~N}$ & $5 \times 20$ \\
\hline (Sri Nurahmani Desi, 2016) & &
\end{tabular}




\section{METODE EKSPERIMEN}

Metode yang digunakan dalam penelitian ini adalah metode pustaka atau studi literatur dengan menggunakan beberapa refrensi dari jurnal untuk mendapatkan hasil penelitian.

Adapun metode yang digunakan dalam penelitian studi pustaka ini ditampilkan pada tabel 2 .

Tabel 2. Metode yang Digunakan

\begin{tabular}{|c|c|c|c|c|}
\hline NO & $\begin{array}{l}\text { BAHAN } \\
\text { DASAR } \\
\text { ORGANIK }\end{array}$ & KOMPOSISI & METODE & PENELITI \\
\hline 1 & Batang Singkong & $\begin{array}{l}\text { - } \text { Batang singkong } \\
\text { ukuran } 8 \text { mesh, } 60 \% \\
\text { - Plastik } \\
\text { Polipropilena (PP) } \\
40 \% \\
\text { - Finir Meranti merah } \\
\text { (Shorea leprosula } \\
\text { Miq) }\end{array}$ & $\begin{array}{l}\text { Batang singkong dan } \\
\text { Plastik Polipropilena } \\
\text { dicampur dan dicetak } \\
\text { dalam cetakan pelat } \\
\text { seng berukuran } 30 \mathrm{~cm} \times \\
30 \mathrm{sm} \times 10 \mathrm{~cm} \text {, yang } \\
\text { telah diberikan finir } \\
\text { pada semua } \\
\text { permukaannya. } \\
\text { Kemudian di beri suhu } \\
180^{\circ} \mathrm{C} \text { dan tekanan } \pm 25 \\
\text { kgf/cm2 selama } 10 \\
\text { menit. Dan di diamkan } \\
\text { selama } 14 \text { hari. }\end{array}$ & (Rita, 2015) \\
\hline 2 & Batang pandan & $\begin{array}{l}\text { - Pandan Mengkuang } \\
\text { ukuran } 8 \text { mesh, } 86 \\
\% \\
\text { - Perekat urea } \\
\text { formaldehida } 14 \% \\
\text { - Paraffin } \\
\text { - Katalis }\end{array}$ & $\begin{array}{l}\text { Batang pandan ukuran } 8 \\
\text { mesh di keringkan pada } \\
\text { suhu } 90^{\circ} \mathrm{C} \pm 5 \text { hari. } \\
\text { Batang pandan dan Urea } \\
\text { Formaldehida dicampur } \\
\text { secara manual dan } \\
\text { dicetak pada ukuran } 30 \\
\mathrm{~cm} \times 30 \mathrm{sm} \times 1 \mathrm{~cm} \\
\text { kemutian diberi lapisan } \\
\text { paraffin dan katalis di } \\
\text { beri } 150^{\circ} \mathrm{C} \text { dan tekanan } \\
\text { spesipik } 25 \text { kg/cm2 } \\
\text { selama } 10 \text { menit, } \\
\text { kemudian dikondisikan } \\
\text { pada suhu ruangan } \\
\text { selama } \pm 7 \text { hari. }\end{array}$ & $\begin{array}{l}\text { (Daeng } \\
\text { Maulana, } \\
\text { 2015) }\end{array}$ \\
\hline 3 & Kayu Akasia & $\begin{array}{lr}\text { - Kayu Akasia } & 70 \% \\
\text { dengan kerapatan } \\
\text { kerapatan } & 0,7 \\
\text { gram/cm } & \\
\text { - Phenol } & \\
& \text { formaldehyde } \\
& (\mathrm{PF}) \\
& \end{array}$ & $\begin{array}{lr}\text { Kayu akasia dengan } & \text { derapatan } 0,7 \text { gram } / \mathrm{cm}^{3} \\
\text { kerap } & \\
\text { di campur dengan } \\
\text { phenol formaldehyde } \\
\text { menggunakan rotary } \\
\text { blender. } \\
\text { kemudian disemprotkan } \\
\text { spray gun sebagai } \\
\text { perekat tambahan. } \\
\text { Bahan kemudian dicetak }\end{array}$ & (Muhdi, 2013) \\
\hline
\end{tabular}




\begin{tabular}{|c|c|c|c|c|}
\hline & & & $\begin{array}{l}\text { dengan ukuran } 35 \mathrm{~cm} \mathrm{x} \\
35 \mathrm{~cm} \text { dan didiamkan } \\
\text { sampai dingin. Setelah } \\
\text { itu } \\
\text { pengempaan pada suhu } \\
160^{\circ} \mathrm{C} \text { selama } 10 \text { menit } \\
\text { dengan tekanan } 24 \\
\mathrm{~kg} / \mathrm{cm}^{2} \text { Kemudian } \\
\text { bahan di diamkan } \\
\text { selama } 2 \text { minggu. }\end{array}$ & \\
\hline 4 & Bambu Kuning & $\begin{array}{l}\text { - Bambu Kulit } 88 \% \\
\text { - Urea Formaldehyd } \\
\text { (UF) } 12 \%\end{array}$ & $\begin{array}{l}\text { Bamboo yang } \\
\text { panjangnya } 30 \mathrm{~cm} \mathrm{di} \\
\text { potong benjadi ukuran } \\
\pm 1,5 \mathrm{~cm} \times 1 \mathrm{~cm} \times 1 \mathrm{~mm} \\
\text { dan dikeringkan hingga } \\
\text { kadar airnya } 12 \% \text {. Urea } \\
\text { Formaldehyd dan } \\
\text { bamboo kemudian di } \\
\text { campur manual dan } \\
\text { dicetak pada ukuran } 25 \\
\mathrm{~cm} \times 25 \mathrm{~cm} \times 2 \mathrm{~cm} \text { lalu } \\
\text { di beri suhu } 120^{\circ} \mathrm{C} \text { pada } \\
\text { tekanan } 20 \mathrm{Kg} / \mathrm{cm}^{2} \\
\text { kemudian di keringkan } \\
\text { selama } 7 \mathrm{hari} \\
\text { (Arhamsyah, 2010) }\end{array}$ & $\begin{array}{l}\text { (Arhamsyah, } \\
\text { 2010) }\end{array}$ \\
\hline 5 & $\begin{array}{l}\text { Serbuk Gergaji } \\
\text { Kayu }\end{array}$ & 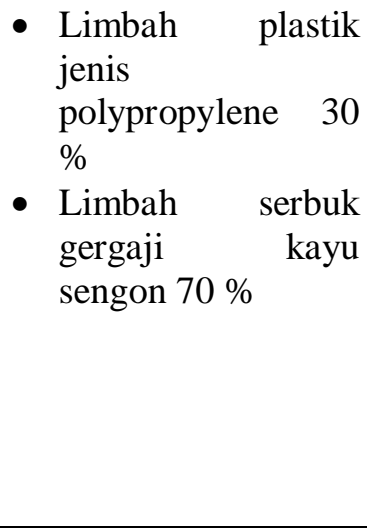 & $\begin{array}{lr}\text { Alat-alat } & \text { yang } \\
\text { digunakan adalah bak } \\
\text { pengaduk, cetakan, } \\
\text { mesin kempa panas, } \\
\text { mesin uji mekanik dan } \\
\text { lain-lain. Pelaksanaan } \\
\text { penelitian meliputi } \\
\text { penyiapan bahan, } \\
\text { pencampuran bahan dan } \\
\text { perekat, pembentukan } \\
\text { mat dan pengempaan } \\
\text { panas (Sushardi, 2015). }\end{array}$ & $\begin{array}{l}\text { (Sushardi, } \\
\text { 2015) }\end{array}$ \\
\hline 6 & Padi & $\begin{array}{l}\text { - } \text { Semen Portland } 80 \\
\% \\
\text { - } \mathrm{CaCl} 22 \%\end{array}$ & $\begin{array}{l}\text { Padi di olah hingga } \\
\text { ukurannya menjadi } 20 \\
\text { mesh }-40 \text { mesh. Setelah } \\
\text { itu padi di rendam } \\
\text { dengan air dingin } \\
\text { selama } 24 \text { jam dan } \\
\text { setelah itu ditiriskan. } \\
\text { Setelah kadar air mulai } \\
\text { berkurang, padi } \\
\text { dicampurkan dengan } \\
\text { semen dan katalis CaCl2 } \\
2 \% \text { Kemudian bahan } \\
\text { dicetak dengan ukuran } \\
30 \mathrm{~cm} \times 30 \mathrm{~cm} \times 1 \mathrm{~cm}\end{array}$ & $\begin{array}{l}\text { (Ratu Fortuna, } \\
\text { 2009) }\end{array}$ \\
\hline
\end{tabular}




\begin{tabular}{|c|c|c|c|c|}
\hline & & & $\begin{array}{l}\text { dan ditekan dengan } \\
\text { tekanan sebesar } 35 \\
\text { kgf/cm }{ }^{2} \text { setelah itu } \\
\text { dioven dengan suhu } \\
60^{\circ} \mathrm{C} \text { selama } 24 \text { jam dan } \\
\text { kemudian di diamkan } \\
\text { selama } 2 \text { minggu (Ratu } \\
\text { Fortuna, 2009). }\end{array}$ & \\
\hline 7 & $\begin{array}{l}\text { Limbah } \\
\text { Industri }\end{array}$ & $\begin{array}{l}\text { - Serbuk kayu Keras } \\
50 \% \\
\text { - } \text { Phenol } \\
\text { formaldehyde (PP) } \\
50 \%\end{array}$ & $\begin{array}{l}\text { Limbah kayu yang } \\
\text { berasal dari industry di } \\
\text { bersihkan kemudian di } \\
\text { perkecil ukurannya dan } \\
\text { dibuat seperti bubur } \\
\text { kayu. Kemudian dari } \\
\text { bubur kayu-adhesive } \\
\text { yang sudah jadi di cetak } \\
\text { dan dipress sesuai } \\
\text { ukuran yang } \\
\text { direncanakan. Dengan } \\
\text { proses pencetakan } \\
\text { kurang lebih } 6 \text { menit } \\
\text { maka jadilah papan } \\
\text { partikel yang masih } \\
\text { dalam keadaan kasar. }\end{array}$ & $\begin{array}{l}\text { (Sushardi, } \\
\text { 2015) }\end{array}$ \\
\hline 8 & Plastik Bambu & $\begin{array}{l}\text { - Serbuk tangkai } \\
\text { bambu tali } 90 \% \\
\text { - Limbah gelas air } \\
\text { mineral yang } \\
\text { bertanda PP } \\
\text { (Polyprophylene) } 10 \\
\% \\
\text { - Pelarut xylene } \\
\text { - NaOH 6\%. }\end{array}$ & $\begin{array}{l}\text { Serbuk bamboo di rebus } \\
\text { dengan larutan NaOH } \\
\text { hingga mendidih. } \\
\text { Setelah itu dikeringkan } \\
\text { kemudian disaring untuk } \\
\text { mendapatkan partikel } \\
\text { bamboo } 30 \text { mesh. } \\
\text { Setelah itu limbah PP } \\
\text { dan xylene di } \\
\text { campurkan pada suhu } \\
170^{\circ} \mathrm{C} \text { kemudian di } \\
\text { tambahbahkan serbuk } \\
\text { bamboo dan setelah } \\
\text { tercampur bahan di } \\
\text { tekan dengan gaya } \\
\text { sebesar 25 kgf/cm²(Ida } \\
\text { Ayu Putu Wida Septiari, } \\
\text { 2014). }\end{array}$ & $\begin{array}{l}\text { (Ida Ayu Putu } \\
\text { Wida Septiari, } \\
\text { 2014) }\end{array}$ \\
\hline 9 & $\begin{array}{l}\text { Sabut } \\
10 \%\end{array}$ & - Lem Kopal 50 \% & $\begin{array}{l}\text { Sabuk kelapa yang telah } \\
\text { dihaluskan dan lem } \\
\text { kopal dicampur dan } \\
\text { dicetak dalam cetakan } \\
\text { berukuran } 12 \mathrm{~cm} \times 1,5 \\
\mathrm{~cm} \times 6 \mathrm{~cm} \text {. Kemudian di } \\
\text { beri suhu } 105^{\circ} \mathrm{C} \text { selama } \\
30 \text { menit. Dan di } \\
\text { diamkan selama } 14 \text { hari }\end{array}$ & (Dina, 2008) \\
\hline
\end{tabular}




\begin{tabular}{llll}
\hline 10 Daun Jambu 50 \% & - Polimer Alami & Daun jambu yang telah & (Heru, 2015) \\
& Getah Karet 50\% & di haluskan kemudian \\
& & dicampurkan dengan \\
& polimer alami getah \\
& karet dan dicetak. \\
& Kemudian papan di beri \\
& tekanan 133,93 MPa. \\
\hline
\end{tabular}

\section{HASIL DAN PEMBAHASAN}

\section{A. Hasil Pengamatan}

Berdasarkan hasil pengamatan dan analisa jurnal, diperoleh data nilai pengujian memanik pada beberapa papan komposit dari bahan dasar organik.

Tabel 3. Hasil Uji Mekanis dan Pengujian Fisis

\begin{tabular}{|c|c|c|c|c|c|c|c|c|}
\hline No & Bahan dasar & Campuran & $\begin{array}{c}\text { Uji } \\
\text { Serap } \\
\text { Air } \\
(\%)\end{array}$ & $\begin{array}{c}\text { Uji } \\
\text { Elastisitas } \\
\left(\mathbf{K g} / \mathrm{cm}^{2}\right)\end{array}$ & $\begin{array}{c}\text { Kerapatan } \\
\left(\mathrm{gr} / \mathrm{cm}^{3}\right)\end{array}$ & $\begin{array}{l}\text { Modulus } \\
\text { Patah } \\
\left(\mathbf{k g} / \mathrm{cm}^{2}\right)\end{array}$ & $\begin{array}{c}\text { Keteguhan } \\
\text { Rekat } \\
\left(\mathbf{k g} / \mathrm{cm}^{2}\right)\end{array}$ & $\begin{array}{c}\text { Kuat } \\
\text { Pegang } \\
\text { Sekrup } \\
\text { (kg) }\end{array}$ \\
\hline 1 & $\begin{array}{l}\text { Kulit Singkong } \\
60 \%\end{array}$ & $\begin{array}{l}\text { Plastik } \\
\text { Polipropilena } \\
\text { (PP) } 40 \%\end{array}$ & 34,35 & 57116,34 & 0,7453 & 473,4539 & 9,0261 & 118,1140 \\
\hline 2 & $\begin{array}{l}\text { Batang Pandan } \\
86 \%\end{array}$ & $\begin{array}{l}\text { Urea } \\
\text { Formaldehida } \\
\text { (UF) }\end{array}$ & 74,40 & 10995,70 & 0,63 & 194,15 & 3,59 & 77,09 \\
\hline 3 & $\begin{array}{l}\text { Kayu Akasia } \\
70 \%\end{array}$ & $\begin{array}{l}\text { Phenol } \\
\text { Formaldehyde } \\
\text { (PF) } 30 \%\end{array}$ & 92,76 & 11135,70 & 0,704 & 76,55 & 1.57 & \\
\hline 4 & $\begin{array}{l}\text { Bambu Kuning } \\
88 \%\end{array}$ & $\begin{array}{l}\text { Urea } \\
\text { Formaldehida } \\
\text { (UF) } 12 \%\end{array}$ & & 14650 & 0,63 & & & \\
\hline 5 & $\begin{array}{l}\text { Serbuk Gergaji } \\
\text { kayu } 70 \%\end{array}$ & $\begin{array}{l}\text { Limbah } \\
\text { Plastik jenis } \\
\text { Polypropylene } \\
30 \%\end{array}$ & 80,76 & 9478,26 & 0.0005151 & 16,1691 & 21,5982 & \\
\hline 6 & Padi $20 \%$ & $\begin{array}{l}\text { Semen } \\
\text { Portland 10\% }\end{array}$ & 24,89 & 22488,61 & 1,26 & 29,63 & 0,58797 & 23,39 \\
\hline 7 & $\begin{array}{l}\text { Limbah Kayu } \\
\text { Industri } 50 \%\end{array}$ & $\begin{array}{l}\text { Phenol } \\
\text { Formaldehyde } \\
\text { (PP) } 50 \%\end{array}$ & & 187,015953 & & & 4,792666 & \\
\hline 8 & $\begin{array}{l}\text { Bambu Hutan } \\
90 \%\end{array}$ & $\begin{array}{l}\text { Limbah } \\
\text { Plastik jenis } \\
\text { Polypropylene } \\
\text { PP } 10 \%\end{array}$ & 302,94 & 324 & & & & \\
\hline 9 & $\begin{array}{ll}\text { Sabut } & \text { Kelapa } \\
10 \% & \\
\end{array}$ & $\begin{array}{l}\text { Lem Kopal } 50 \\
\%\end{array}$ & & 642,672 & 0,58 & 24,55 & & \\
\hline 10 & $\begin{array}{l}\text { Daun Jambu } \\
50 \%\end{array}$ & $\begin{array}{l}\text { Polimer } \\
\text { Alami Getah } \\
\text { Karet } 50 \%\end{array}$ & 28 & & 0,68 & & & \\
\hline
\end{tabular}

\section{B. Pembahasan}

Berdasarkan data diatas dapat dilihat bahwa papan komposit dengan daya serap paling besar adalah kayu akasia. Hasil penelitian menunjukkan bahwa faktor jenis bahan baku dan variasi jenis perekat mempengaruhi daya serap air papan partikel yang dihasilkan. Sedangkan yang memiliki daya serap terkecil adalah Bambu kuning. Hal ini disebabkan selain terdapatnya lapisan lilin pada bagian luar kulit yang dapat menghalangi masuknya air, juga disebabkan oleh perbedaan struktur anatomi bambu pada bagian dalam, tengah dan luar. Pada bagian luar, bambu tali memliki pori-pori dengan diameter yang lebih kecil $(0,078 \mathrm{~mm}-0,105 \mathrm{~mm})$ dibandingkan dengan bagian 
tengah $(0,15-0,176 \mathrm{~mm})$ dan bagian dalam $(0,217 \mathrm{~mm}-0,248 \mathrm{~mm})$. Dengan demikian anyaman bambu tanpa kulit, lebih mudah menyerap air dibandingkan bambu dengan kulit.

Untuk Uji Elastisitas, padi menjadi bahan dasar organik pembuatan papan komposit dengan elastisitas yang sangat tinggi yaitu $57116,34 \mathrm{Kg} / \mathrm{cm}^{2}$. Hal ini disebabkan karena diaantara semua bahan campuran organik, padi menggunakan campuran berupa Plastik Polipropilena (PP) 40\%. Sedangkan untuk elastisitas yang rendah diduduki oleh bambu kulit dengan elastisitas $6,22 \mathrm{Kg} / \mathrm{cm}^{2}$. Hal ini dapat dimengerti karena bambu dalam bentuk anyaman tersusun atas bilah-bilah dengan arah serat yang tidak seragam, yaitu tegak lurus maupun miring atau dengan kata lain membentuk sudut dengan arah panjang papan, sehingga mempengaruhi kekuatan papan komposit yang dihasilkan.

Untuk pengujian kerapatan papan komposit, data yang di peroleh hanya menunjukkan ada empat papan komposit yang mendapatkan pengujian tingat kerapatang yaitu kulit singkong, batang pandan, kayu akasia, bambu kuning, serbuk gergaji kayu, dan sekam padi. Dari hasil pengujian didapatkan nilai kerapatan paling tinggi yaitu papan komposit yang menggunakan padi dan semen Portland sedangkan nilai paling kecil ditunjukkan oleh papak komposit yang menggunakan serbuk gergaji kayu.

Untuk pengujian lainnya dapat di tunjukkan pada tabel VI.1. Dengan mengacu pada tabel II.1 yaitu standar SNI pembuatan papan komposit, hasil penelitian di atas telah memenuhi standar. Dari hasil penelitian menunjukkan papan komposit yang memiliki nilai dan kualitas terbaik adalah papan komposit dengan menggunakan bahan dasar organik kulit singkong dan plastik Polipropilena dengan perbandingan $60 \%$ : $40 \%$. Kualitas terbaik tersebut ditunjukkan oleh data yang dihasilkan dimana nilai uji daya serap air, uji elastisitas, kerapatan, modulus patah, keteguhan rekat, dan kuat pegang sekrup pada papan komposit dengan bahan dasar kulit singkong secara berurut adalah $34,35 \%, 57116,34 \mathrm{Kg} / \mathrm{cm}^{2}, 0,7453 \mathrm{gr} / \mathrm{cm}^{3}, 473,4539 \mathrm{~kg} / \mathrm{cm}^{2}, 9,0261 \mathrm{~kg} / \mathrm{cm}^{2}$, dan $118,1140 \mathrm{Kg}$.

\section{KESIMPULAN}

Kesimpulan pada penelitian ini adalah:

1. Metode pembuatan papan komposit dari bahan organik dapat dilakukan dengan mencampurkan material organic yang telah di hancurkan ke dalam bentuk yang lebih kecil dengan bahan perekat tertentu dan di keringkan pada suhu tertentu dan pada tekanan yang tertentu dan selanjutnya didiamkan beberapa waktu.

2. Papan komposit dengan kualiatas terbaik ada papan yang terbuat dari kayu Akasia dengan campuran Phenol Formaldehyde denganhasil pengujian nilai uji daya serap air, uji elastisitas, kerapatan, modulus patah, keteguhan rekat, dan kuat pegang sekrup pada papan komposit dengan bahan dasar kulit singkong secara berurut adalah 34,35\%, 57116,34 Kg/cm2, 0,7453 gr/cm3, 473,4539 kg/cm2, 9,0261 $\mathrm{kg} / \mathrm{cm} 2$, dan $118,1140 \mathrm{Kg}$. 


\section{DAFTAR PUSTAKA}

Arhamsyah, Nazami Rahmi. (2010). Pengaruh Kadar Perekat dan Jenis Bambu Terhadap Sifat Fisis dan Mekanis Papan Partikel. Jurnal Riset Industri Hasil Hutan, 2(1).

Ayu, Ida dkk. (2014). Pembuatan Papan Partikel dari Limbah Plastik Polipropilena dan Tangkai Bambu. Jurnal, 2(1).

Cahyandari, Dini. (2007). Pemanfaatan Limbah Kayu Sebagai Bahan Dasar Pembuatan Papan Partikel. Traksi., 5(1).

Damayani, Heru dkk. (2015). Pemanfaatan Limbah Daun Jambu dan Polimer Alami Getah Karet Sebagai Bahan Alternatif Furniture. Jurnal Fisika, 5(1).

Desi, Sri Nurahmani. (2016). Uji Kualitas Material Papan Komposit Bahan dari Serbuk Kayu dan Kertas dengan Perekat Limbah Plastik. [Skripsi]. UIN Alauddin Makassar

Fortuna, Ratu. (2009). Kualitas Papan Semen Dari Sekam Padi (Oryza sativa Linn). [Skripsi]. Departemen Hasil Hutan Fakultas Kehutanan Institut Pertanian Bogor

Karyawan, I Kadek Eka dkk. (2017). Pembuatan Papan Komposit dari Limbah Plastik Poluvinyl Chloride (PVC) dan Limbah Batang Jagung. Jurnal, 11(2).

Maulana, Farid dkk. (2011). Pembuatan Papan Komposit Dari Plastik Daur Ulang dan Serbuk Kayu serta Jerami Sebagai Filler. Jurnal, 8(1), 17-22.

Maulana, Daeng dkk. (2015). Karakterisasi Papan Partikel dari Batang Pandan Mengkuang (Pandanus atrocarpus Griff) Berdasarkan Ukuran Partikel dan Konsentrasi Ureaformaldehida. Jurnal, 3(2), $247-258$.

Risnasari I, Muhdi dkk, (2013). Studi Pembuatan Papan Partikel dari Limbah Pemanenak Kayu Akasia (Acacia mangium L.). Jurnal, 15(1), 14-19.

Rita, Ronnita. (2015). Sifat Fisik dan Mekanik Papan Komposit dari Batang Singkong dan Limbah Plastik Berdasarkan Pelapisan dan Komposisi Bahan Baku. Jurnal, 3(2), 337-346.

Setyawati, Dina. (2008). Karakterisasi Papan Komposit dari Serat Sabut Kelapa dan Plastik Polypropylene Daur Ulang Berlapis Anyaman Bambu. Jurnal Ilmu dan Teknologi Hasil Hutan, 1(1), 18-26.

Veranitha, Sushardi. (2015). Papan Komposit dari Limbah Industri dengan Perekat Campuran Plastik Polipropilena. ISBN : 978-602-14930-3-8. 